\title{
Salmonella Count Changes in Fermentation of Poultry Farm Waste
}

\author{
I. A. Baba ${ }^{1 *}$, M. T. Banday ${ }^{1}$, H. M. Khan ${ }^{1}$, A. A. Khan ${ }^{1}$ and M. M. Darzi ${ }^{2}$ \\ ${ }^{1}$ Division of Livestock Production and Management, Sheri-e-Kashmir University of \\ Agricultural Sciences and Technology of Kashmir, India \\ ${ }^{2}$ Faculty of Veterinary Sciences and Animal Husbandry Shuhama, Sheri-e-Kashmir University \\ of Agricultural Sciences and Technology of Kashmir, India \\ *Corresponding author
}

\section{A B S T R A C T}

The present study was conducted in the Division of Livestock Production and Management, Faculty of Veterinary Sciences and Animal Husbandry (SKUAST- Kashmir) to assess the Salmonella count changes in the poultry farm waste different seasons of fermentation. Poultry farm waste in the form of poultry carcass (dead birds) and poultry litter was selected for this purpose. Nine treatment recipes formulated for fermentation

\section{Keywords}

Salmonella Count,

Fermentation,

Poultry Farm Waste

Article Info

Accepted:

20 May 2018

Available Online:

10 June 2018 were: $\mathrm{T}_{1}$ :Poultry carcass + Poultry litter, $\mathrm{T}_{2}:$ Poultry carcass + Poultry litter + Lactobacillus @ 1.0 per cent $\mathrm{T}_{3}$ :Poultry carcass + Poultry litter + Lactobacillus @ 0.5 per cent $\mathrm{T}_{4}$ : Poultry carcass + Poultry litter + Yeast @ 1.0 per cent $\mathrm{T}_{5}$ : Poultry carcass + Poultry litter + Yeast@0.5 per cent $\mathrm{T}_{6}$ : Poultry carcass + Poultry litter + Lactobacillus @ 1per cent + Yeast@0.5per cent $\mathrm{T}_{7}$ : Poultry carcass + Poultry litter + Lactobacillus @ 1per cent + Yeast@1per cent $\mathrm{T}_{8}$ : Poultry carcass + Poultry litter + Lactobacillus @ 0.5per cent + Yeast@0.5per cent $\mathrm{T}_{9}$ : Poultry carcass + Poultry litter + Lactobacillus @ 0.5per cent + Yeast @ 1 per cent. At initial stage the overall highest Salmonella count of $8.58 \log _{10} \mathrm{cfu}$ was observed in $\mathrm{T}_{2}$. At final stage, the significantly $(\mathrm{P}<0.05)$ highest Salmonella count of $1.08 \log _{10} \mathrm{cfu} / \mathrm{g}$ was observed $\mathrm{T}_{1}$ (control group) and non-detectable Salmonella count was observed in all other treatments (except $\mathrm{T}_{3}$ and $\mathrm{T}_{4}$ ) during winter season. Similarly during summer season significantly $(\mathrm{P}<0.05)$ highest and lowest Salmonella count of 1.08 $\log _{10} \mathrm{cfu} / \mathrm{g}$ in was observed in treatment group $\mathrm{T}_{1}$ (control group) and non-detectable (ND) levels of Salmonella count was observed in all other treatments. There was a drastic reduction in the Salmonella count from initial to secondary stage of composting during both the seasons. It was concluded that fermentation significantly reduces Salmonella bacteria in the poultry farm waste to give a secure and safe end product.

\section{Introduction}

The Indian poultry industry is the fastest growing segment of the livestock sector with $12.39 \%$ present annual growth rate (Anon. 2015). With high levels of concentrated production, it involves generation of large volumes of waste. One of the major problems currently faced by the poultry industry is the accumulation of a large amount of waste especially manure and litter generated by intensive production (Bolan, 2010). There has been an increasing concern about the presence of infectious pathogenic bacteria in the poultry 
farm waste which causes different problems both for animals as well as humans (Russell et al., 1992). Poultry farm waste in the form of dead birds, offal and litter is currently being processed and utilized as feed or manure. However, the method of processing and handling of such waste results in the final product contamination (Kostrzynska and Bachard, 2006). Fermentation of poultry carcasses is a bio-secure method of disposal and utilization of poultry farm waste. It is an anaerobic process in which lactic acid bacteria transform sugar into lactic acid which is a naturally low $\mathrm{pH}$ effective preservative agent (Cai and Pancorbo, 1994). The lactic acid fermentation helps in decontamination of poultry farm waste to generate safe and secure final product (Crews et al., 1995). The objective of this study was to determine the changes of Salmonella count in fermentation of poultry farm waste.

\section{Materials and Methods}

Fermentation of the poultry farm waste (dead birds and poultry litter) was carried out at Division of LPM under a roofed shed. The fermentation process was carried out in air tight plastic containers. Dead birds and poultry litter in 1:1 ratio was fermented in different combinations. Poultry waste was humidified with tap water in the proportion of $1: 1$ and the $\mathrm{pH}$ was adjusted to 6.5 with $50 \% \mathrm{H}_{2} \mathrm{SO}_{4}$ solution (El-Jalil et al., 2008). A total of nine treatments (with three replicates in each treatment) with different individual as well as combination levels of culture of Lactobacillus acidophilus and Yeast (Saccharomyces cerevisiae) was used as shown in Table: 1. Dead birds and poultry litter was collected from local poultry farms. The dead birds were stored at $-5^{\circ} \mathrm{C}$ till sufficient materials were made available to fill all the containers in a single day. On the receipt of sufficient quantity of carcasses and poultry litter, the filling of fermentation containers was carried out uniformly. For Salmonella count changes the samples were collected at the time of loading (by mixing all the ingredients thoroughly and taking samples) and at the end of secondary stage in a serial polythene bags and sealed air tight. The samples were serially diluted in 10 fold steps using sterile triple glass distilled water. The Salmonella Shigella agar was used as selective media. The selective media was incubated aerobically for 1 day at $37^{\circ} \mathrm{C}$. The microbial numbers were expressed as $\log _{10}$ colony forming units per gram of sample (Quinn et al., 1992).

\section{Statistical analysis}

The data was statistically analyzed as per the methods suggested by Snedecor and Cochran (1994). SPSS software was used for comparing the means using one way ANOVA.

\section{Results and Discussion}

At initial stage, the significantly highest $(\mathrm{P}<0.05) \quad$ Salmonella count recorded was $11.33 \log _{10} \mathrm{cfu} / \mathrm{g}$ in $\mathrm{T}_{1}$ (control group) and lowest Salmonella count recorded was $9.0 \log _{10} \mathrm{cfu} / \mathrm{g}$ in treatment group $\mathrm{T}_{6}$ (in which Lactobacillus@1\% and Yeast@0.5\% was added) was observed during winter season (Table. 2). Similarly during summer season significantly $(\mathrm{P}<0.05)$ highest and lowest Salmonella count of 11.33 and $8.25 \log _{10} \mathrm{cfu} / \mathrm{g}$ was observed respectively in treatment groups of $\mathrm{T}_{2}$ (in which Lactobacillus@ 1\%) and $\mathrm{T}_{9}$ (Lactobacillus@0.5\% and Yeast@1\% was added) respectively. There was a significant $(\mathrm{P}<0.05)$ effect of two seasons on the Salmonella count in $\mathrm{T}_{2}$ (Lactobacillus@1\%), $\mathrm{T}_{4}$ (Yeast@1\%), $\mathrm{T}_{5}$ (Yeast@ 0.5) and $\mathrm{T}_{7}$ (Lactobacillus@1\% and Yeast@ 1\%) treatments only. The overall highest Salmonella count of $11.04 \log _{10} \mathrm{cfu} / \mathrm{g}$ was observed in $\mathrm{T}_{1}$ (control group). At final stage, the significantly $(\mathrm{P}<0.05)$ highest Salmonella count of $1.08 \log _{10} \mathrm{cfu} / \mathrm{g}$ in was observed $\mathrm{T}_{1}$ 
(control group) and non-detectable Salmonella count was observed in all other treatments (except $\mathrm{T}_{3}$ and $\mathrm{T}_{4}$ ) during winter season. Similarly during summer season significantly $(\mathrm{P}<0.05)$ highest and lowest Salmonella count of $1.08 \log _{10} \mathrm{cfu} / \mathrm{g}$ in was observed in treatment group $\mathrm{T}_{1}$ (control group) and non-detectable (ND) levels of Salmonella count was observed in all other treatments. The overall lowest nondetectable (ND) levels of Salmonella count was observed in treatment groups of $\mathrm{T}_{2}, \mathrm{~T}_{5}$, $\mathrm{T}_{6}, \mathrm{~T}_{7}, \mathrm{~T}_{8}$ and $\mathrm{T}_{9}$. There was significant $(\mathrm{P}<0.05)$ reduction in Salmonella count from initial to final stage of fermentation in all treatment groups (Table. 3 ).

Lactic acid bacteria exhibit an antibacterial activity by using the double layer inhibition method against the different strains of Salmonella spp (Sakaridis et al., 2012). Initially the Salmonella count varied significantly $(\mathrm{P}<0.05) \quad$ between 9.0 in treatment group $\mathrm{T}_{6}$ and $11.33 \log _{10} \mathrm{cfu} / \mathrm{g}$ in treatment group $\mathrm{T}_{1}$ during winter and 8.24 in treatment group $T_{9}$ and $11.33 \log _{10} \mathrm{cfu} / \mathrm{g}$ in treatment group $\mathrm{T}_{2}$ during summer season (Table. 2). However at the end of final stage Salmonella count reduced to non-detectable (ND) levels in all the treatment groups (except treatment groups of $\mathrm{T}_{1}, \mathrm{~T}_{3}$ and $\mathrm{T}_{4}$ ). A significantly $(\mathrm{P}<0.05)$ higher drastic reduction in Salmonella count was noticed from initial to final stage of fermentation (Table. 3). Although the Salmonella count in $\mathrm{T}_{1}, \mathrm{~T}_{3}$ and $\mathrm{T}_{4}$ was detectable but the levels recorded were significantly as low as $1.08,0.5$ and $0.41 \log _{10}$ cfu/g respectively. Earlier Sakaridis et al., (2014) reported a comparable inhibitory effect of Lactic acid bacterial on Salmonella count on fermented chicken carcass to nondetectable levels. Contrary to this El-Jalil et al., (2008) observed only a 50 per cent reduction in Salmonella count due to lactic acid fermentation of poultry manure waste. Callewaert and De Vuyst (2000) found that various inhibitory substances (organic acids, diacetyl, bacteriocins, hydrogen peroxide) are generated from lactic acid bacteria which would suppress the growth of pathogenic bacteria like Salmonella.

Table.1 Treatment Combinations of Fermentation Experiment

\begin{tabular}{|c|c|}
\hline Treatments & Description \\
\hline Treatment 1 & Dead birds + Poultry litter \\
\hline Treatment 2 & Dead birds + Poultry litter + lactobacillus @ $1.0 \%$ \\
\hline Treatment 3 & Dead birds + Poultry litter + lactobacillus @ $0.5 \%$ \\
\hline Treatment 4 & Dead birds + Poultry litter + Yeast @ $1.0 \%$ \\
\hline Treatment 5 & Dead birds + Poultry litter + Yeast @ $0.5 \%$ \\
\hline Treatment 6 & Dead birds + Poultry litter + Lactobacillus@ 1\% + Yeast@ 0.5\% \\
\hline Treatment 7 & Dead birds + Poultry litter + Lactobacillus@1\%+Yeast@1\% \\
\hline Treatment 8 & Dead birds + Poultry litter+Lactobacillus@0.5\%+Yeast @0.5\% \\
\hline Treatment 9 & Dead birds + Poultry litter + Lactobacillus@0.5\%+Yeast @1\% \\
\hline
\end{tabular}


Table.2 Salmonella count $\left(\log _{10} \mathrm{cfu} / \mathrm{g}\right)$ due to fermentation during different stages and seasons (Mean $\left.\pm \mathrm{SE}\right)$

\begin{tabular}{|c|c|c|c|c|c|c|}
\hline \multirow[t]{2}{*}{ Treatment } & \multicolumn{3}{|c|}{ Initial } & \multicolumn{3}{|c|}{ Final } \\
\hline & Winter & Summer & Overall & Winter & Summer & Overall \\
\hline$\overline{T_{1}}$ & ${ }^{\mathrm{B}} 11.33 \pm 0.34$ & ${ }^{\mathrm{AB}} 10.75 \pm 0.24$ & $11.04 \pm 0.15$ & $1.08 \pm 0.04$ & $1.08 \pm 0.04$ & $1.08 \pm 0.01$ \\
\hline $\mathrm{T}_{2}(\mathrm{LB}=1 \%)$ & ${ }^{\mathrm{AB}} 9.66 \pm 0.76^{\mathrm{a}}$ & ${ }^{\mathrm{B}} 11.33 \pm 0.37^{\mathrm{b}}$ & $10.49 \pm 0.13$ & $N D$ & $N D$ & ND \\
\hline $\mathrm{T}_{3}(\mathrm{LB}=0.5 \%)$ & ${ }^{\mathrm{AB}} 10.0 \pm 0.44$ & ${ }^{\mathrm{AB}} 9.91 \pm 0.71$ & $9.95 \pm 0.42$ & $1.00 \pm 0.32$ & $N D$ & $0.50 \pm 0.02$ \\
\hline $\mathrm{T}_{4}($ Yeast $=1 \%)$ & ${ }^{\mathrm{AB}} 10.66 \pm 0.62^{\mathrm{a}}$ & ${ }^{\mathrm{AB}} 9.50 \pm 0.60^{\mathrm{b}}$ & $10.08 \pm 0.43$ & $0.83 \pm 0.25$ & $N D$ & $0.41 \pm 0.01$ \\
\hline$T_{5}($ Yeast $=0.5 \%)$ & ${ }^{\mathrm{AB}} 9.41 \pm 0.28$ & ${ }^{\mathrm{AB}} 8.41 \pm 0.17$ & $8.91 \pm 0.14$ & $N D$ & $N D$ & $N D$ \\
\hline $\mathrm{T}_{6}(\mathrm{LB}=1 \%+\mathrm{Yeast}=0.5 \%)$ & ${ }^{\mathrm{A}} 9.0 \pm 0.46$ & ${ }^{\mathrm{AB}} 8.33 \pm 0.62$ & $8.66 \pm 0.20$ & $N D$ & $N D$ & $N D$ \\
\hline $\mathrm{T}_{7}(\mathrm{LB}=1 \%+\mathrm{Yeast}=1 \%)$ & ${ }^{\mathrm{AB}} 10.33 \pm 0.19^{\mathrm{a}}$ & ${ }^{\mathrm{AB}} 8.58 \pm 0.48^{\mathrm{b}}$ & $9.45 \pm 0.09$ & $N D$ & $N D$ & $N D$ \\
\hline$T_{8}(L B=0.5+$ Yeast $=0.5 \%)$ & ${ }^{\mathrm{AB}} 9.25 \pm 0.08$ & ${ }^{\mathrm{AB}} 8.83 \pm 0.66$ & $9.04 \pm 0.04$ & $N D$ & $N D$ & $N D$ \\
\hline $\mathrm{T}_{9}(\mathrm{LB}=0.5+$ Yeast $=1 \%)$ & ${ }^{\mathrm{A}} 9.16 \pm 0.25$ & A $8.25 \pm 0.38$ & $8.70 \pm 0.12$ & $N D$ & $N D$ & $N D$ \\
\hline
\end{tabular}

Figures with different small superscripts row wise and capital superscripts column wise differ significantly $(\mathrm{P}<0.05)$.

Table.3 Changes in Salmonella count $\left(\log _{10} \mathrm{cfu} / \mathrm{g}\right)$ due to fermentation from initial to final stages during different seasons (Mean \pm SE)

\begin{tabular}{|c|c|c|c|c|}
\hline \multirow[t]{2}{*}{ Treatment } & \multicolumn{2}{|c|}{ Winter } & \multicolumn{2}{|c|}{ Summer } \\
\hline & Initial stage & Final stage & Initial stage & Final stage \\
\hline $\mathbf{T}_{1}$ & ${ }^{\mathrm{B}} 11.33 \pm 0.34^{\mathrm{a}}$ & $1.08 \pm 0.04^{\mathrm{b}}$ & ${ }^{\mathrm{AB}} 10.75 \pm 0.24^{\mathrm{a}}$ & $1.08 \pm 0.04^{b}$ \\
\hline $\mathrm{T}_{2}(\mathrm{LB}=1 \%)$ & ${ }^{\mathrm{AB}} 9.66 \pm 0.76$ & $N D$ & ${ }^{\mathrm{B}} 11.33 \pm 0.37$ & $N D$ \\
\hline $\mathrm{T}_{3}(\mathrm{LB}=0.5 \%)$ & ${ }^{\mathrm{AB}} 10.0 \pm 0.44^{\mathrm{a}}$ & $1.00 \pm 0.32^{b}$ & ${ }^{\mathrm{AB}} 9.91 \pm 0.71$ & $N D$ \\
\hline $\mathrm{T}_{4}($ Yeast $=1 \%)$ & ${ }^{\mathrm{AB}} 10.66 \pm 0.62^{\mathrm{a}}$ & $0.83 \pm 0.25^{b}$ & ${ }^{\mathrm{AB}} 9.50 \pm 0.60$ & $N D$ \\
\hline $\mathrm{T}_{5}($ Yeast $=0.5 \%)$ & ${ }^{\mathrm{AB}} 9.41 \pm 0.28$ & $N D$ & ${ }^{\mathrm{AB}} 8.41 \pm 0.17$ & $N D$ \\
\hline $\mathrm{T}_{6}(\mathrm{LB}=1 \%+$ Yeast $=0.5 \%)$ & ${ }^{\mathrm{A}} 9.0 \pm 0.46$ & $N D$ & ${ }^{\mathrm{AB}} 8.33 \pm 0.62$ & $N D$ \\
\hline $\mathrm{T}_{7}(\mathrm{LB}=1 \%+$ Yeast $=1 \%)$ & ${ }^{\mathrm{AB}} 10.33 \pm 0.19$ & $N D$ & ${ }^{\mathrm{AB}} 8.58 \pm 0.48$ & $N D$ \\
\hline $\mathrm{T}_{8}(\mathrm{LB}=0.5+Y$ east $=0.5 \%)$ & ${ }^{\mathrm{AB}} 9.25 \pm 0.08$ & $N D$ & ${ }^{\mathrm{AB}} 8.83 \pm 0.66$ & $N D$ \\
\hline $\mathrm{T}_{9}(\mathrm{LB}=0.5+$ Yeast $=1 \%)$ & ${ }^{\mathrm{A}} 9.16 \pm 0.25$ & $N D$ & ${ }^{\mathrm{A}} 8.25 \pm 0.38$ & $N D$ \\
\hline
\end{tabular}

Figures with different small superscripts row wise and capital superscripts column wise differ significantly $(\mathrm{P}<0.05)$. 
The lactic bacteria is capable of producing and discharging into the environment a great variety of antimicrobial substances (bacteriocins), which inhibit the development of microorganisms not suitable for fermentation (Wang et al., 2001).

The lactic acid and yeast fermentation of poultry farm waste yields a safe and secure fermented end product which can be utilized either as feed or manure. Salmonella count was drastically reduced due to acidic $\mathrm{pH}$ of the fermentation mixture and hence either very low or un-detectable Salmonella was found.

\section{Acknowledgement}

Authors are highly thankful to Head, Division of Veterinary Public Health (FVSc and AH) for providing the support for this study.

\section{References}

Anonymous. 2015. Annual Report of Department of Animal Husbandry, Dairying and Fisheries, Ministry of Agriculture, Govt. of India, 34.

Bolan, NS, Szogi, AA, Chuasavathi, TB, Seshadri, MJ, Rothrock JR, Panneerselvam, P. 2010. Uses and Management of Poultry Litter. World's Poultry Science Journal, 66: 673-698.

Cai, T. and Pancorbo, O. C. 1994. Chemical and microbiological characteristics of poultry processing byproducts, waste and poultry carcasses during lactic acid fermentation, Journal of Applied Poultry Science Research: 3: 49-60.

Callewaert, R. and L. De Vuyst, 2000. Bacteriocin production with Lactobacillus amylovuirus DCE 471 is improved and stabilized by feed batch fermentation. Appl. Environ. Microbiol., 66: 606-13.
Crews, JR, Donald JO, Blake, JP, 1995. An Economic Evaluation of Dead-bird Disposal Systems. ANR-914.Alabama Cooperative Extension System. Blake and P. H. Patterson (editors). Proceedings of National Poultry Waste Management Symposium. Oct 30-Nov 02, Athens, Georgia, 304309.Anonymous, 2015.

El-Jalil, M. H., Zinedine, A and. Faid, M. 2008. Some microbiological and chemical properties of poultry wastes manure after lactic acid fermentation. International Journal of Agricultural Biology, 10: 405-11.

Kostrzynska M., Bachand A. 2006. Use of microbial antagonism to reduce pathogen levels on produce and meat products: a review. Canadian Journal of Microbiology, 52: 1017-1026.

Quinn, P. J., Carter, M. E., Markey, B. K and Carter, G. R. 1992. Clinical Veterinary Microbiology. Mosby-Year book Europe Limited. London, pp. 61-65.

Russell, S. M., Fletcher, D. L. Pancorbo, O. C and Merka, W. C. 1993. Effect of Lactic Acid Fermentation on Bacterial Pathogens and Indicator Organisms in Broiler Processing Waste. Poultry Science, 72:1573-1576.

Sakaridis I., Soultos N., Dovas C.I., Papavergou E., Ambrosiadis I., Koidis P. 2012. Isolation and identification of lactic acid bacteria from chicken carcasses with inhibitory activity against Salmonella spp. and Listeria monocytogenes. Anaerobe, 18: 62-66.

Sakaridis, I., Soultos, N., Batzios, C., Ambrosiadis, I and Koidis, P. 2014. Lactic acid bacteria isolated from chicken carcasses with inhibitory activity against Salmonella spp. and Listeria monocytogenes. Czech Journal Food Science, 32: 61-68.

Snedecor, G.W. and Cochran, W.G. 1994. Statistical Methods 8th Edition, Iowa 
State Press, Ames, Iowa, USA. pp: 254268.

Wang, Q., K. Yamabe, J. Narita, M. Morishita, Y. Ohsumi, K. Kusano, Y. Shirai and H.I. Ogawa, 2001.
Suppression of growth of putrefactive and food poisoning bacteria by lactic acid fermentation of kitchen waste. Process Biochem., 37: 351-7.

\section{How to cite this article:}

Baba I. A., M. T. Banday, H. M. Khan, A. A. Khan and Darzi M. M. 2018. Salmonella Count Changes in Fermentation of Poultry Farm Waste. Int.J.Curr.Microbiol.App.Sci. 7(06): 22382243. doi: https://doi.org/10.20546/ijcmas.2018.706.266 